No. 20.]

\title{
TRA NSACTIONS
}

OF THE

\section{FACULTY OF ACTUARIES.}

The English Land Registry. By JAMES ROBERT HART, F.I.A., of the Pelican and British Empire Life Office, London.

[Read before the Faculty, 23 January 1905.]

IT has become important for members of our profession to know something of the English Land Registration system. Our future practice in dealing with mortgages may be materially affected by it; moreover, the question of its extension has reached a stage at which nearly every one, in England at least, is called upon to consider and form an opinion as to its merits. Here, too, the public has some practical interest in the question. It is quite probable there may be a demand for the extension of the system to this part of the kingdom; in fact, I am told that a deputation from Glasgow has already inspected the London Registry with this idea in view. In the following remarks, therefore, I shall try to bring together the chief features of registration of title to land according to the English system, and explain the circumstances under which it is being worked at the present time. The treatment of such a subject is not without difficulties. It necessarily involves a number of intricate legal points, and without a thorough knowledge and experience of English land laws, one is not in the position to follow it in all its bearings. But although I cannot attempt to deal with all the legal questions that arise, I think there may even be some advantage in a paper by one who is not a lawyer. There cannot be the same charge of bias; and it is possible that the points more particularly affecting such a profession as ours, may be more prominently brought out by one of its own members.

Before coming to the main part of the subject, it is necessary VOL. II. 
briefly tc notice the process of dealing with land under the existNon- ing non-registration system. When a property is sold Registration or mortgaged, the vendor or mortgagor has to prove Process. his title. To do this, he furnishes an abstract containing a statement of every dealing or event affecting the devolution of the property during the time for which title has to be proved; and he produces deeds, documents, and certificates in support of this statement, proving that he is the person entitled to sell or mortgage the land. The evidence submitted is then examined by the purchaser's solicitor. If he advises his client to accept it, a conveyance is drawn up and the transaction completed. In many cases the evidence may not be absolutely conclusive, but if it is reasonably sufficient it is accepted. Although there may be technical flaws, there may be what is called "a good holding title". If the dealings have been few and simple, the arrangements can be carried out without much trouble or loss of time; but sometimes, especially in cases of large value, the purchaser's solicitor will have to consult counsel, who may raise all sorts of questions before he will feel satisfied with the title his client is to get. This part of the process is often particularly irritating to the ordinary business man. From the technical nature of the complications, he can do little to press matters forward, and he has to wait while requisitions on title, replies to requisitions, and remarks on replies, go backwards and forwards; till finally, perhaps, the process comes to a deadlock, and he is then advised that if he wants the property he will have to give way and accept something less in the shape of evidence than his legal advisers think he should have had. If the trausaction is a mortgage, where the investigation of title is more stringent, the mortgagee may either have to take a risk he did not bargain for, or relinquish the loan, over which he may have spent some trouble. I need hardly say that matters are not assisted, but rather the reverse, if a layman who has a smattering of law tries to carry the matter through some of the stages generally left to the lawyers. Quite recently I had before me the case of a small sale of land, where it took some weeks to get through the preliminary stages of settling the draft contract, owing to the purchaser himself arguing as to the effect of "beneficial owner", the "length of title", and other technical points which under present conditions must be left to the lawyers.

Besides troublesome complications and loss of time sometimes involved in the process under the non-registration system, there is the question of cost. Generally speaking, both sides have to employ a solicitor; and though if one compares his fees with those earned in most other professions, and takes into account the time and skill required to unravel the intricacies I have men- 


\section{The English Land Registry}

tioned and the responsibility incurred, one cannot consider them high, yet commercial clients, who are used to deal with their commodities or with stock or shares in a simple and rapid way, generally view this attribute of land ownership with some disfavour. And it should be borne in mind that this expenditure of time, trouble, and money has to be repeated at each dealing with the property. For what was good evidence of title to one mind may not be to another, and the result of the investigation will partly depend on the skill and experience brought to bear upon it.

While pointing out these defects of the non-registration system, I would not, however, overlook its good features. The process is often far less troublesome and lengthy than might be supposed. Sometimes, especially in dealing with a leasehold interest, the evidence of title required may be of quite a simple character, and a transaction quickly settled. Moreover, there is a certain degree of elasticity in the existing method of conveyancing which enables it to be adapted to complicated as well as simple cases better than what might appear to be more reasonable methods. The Conveyancing Act 1881 , it will be remembered, introduced great improvements; and the ordinary forms of conveyance and mortgage are now fairly short, simple, and easily understood. But even taking the most favourable view of the process, it is generally agreed that there is room for improvement in the simplification of titles; not only to obviate the loss of time involved in the repeated investigations under the present process, but also to enable a person of average intelligence, at least to keep in touch with the arrangements more closely than is possible at present. There is nothing inherent in land, it is said by the promoters of registration of title, to make dealings with it more complicated than with stock or shares. There are, of course, interests and conditions attaching to the ownership of land that do not enter into the possession of other classes of property-for example, the rights of freeholder and leaseholder, questions of boundary, building restrictions, rights of way, and such like; but it is said these need offer no obstacle to simplicity of dealing. To support this contention, the success of the registration system in other parts of the world is adduced. There is, however, another feature of English land tenure to be kept in view. The land laws are intricate and complicated; and if simplicity of dealing is to be attained, there would seem to be need for radical changes in this respect. In the last few pages of Williams's Real Property, which I suppose may be regarded as an authority, the conditions are summed up. After remarking on the complexity of the modern law of real property, the author of that work goes on to explain how this is not owing, as has been commonly supposed, to the 
feudal system or to the subtlety of the judges who formulated the early common law with regard to land, but in a great measure to the action of the English landowners, who from the earliest times were possessed with the idea of assuring their lands to themselves and their descendants by means of family settlements, and in modern times desired to effect this object without losing the benefit of the powers of alienation incident to full ornership. The simplicity of an estate in fee simple was arrived at in very early times, but complications were subsequently introduced as the result of landowners' determination to make settlements and to provide for a great variety of limitations, until we come to the time of the Settled Land Acts, which, though conferring a substantial benefit upon the owners of settled land, it is said certainly do not simplify the law. "But another main reason for the "intricacy of the present land laws is the manner in which they "have been altered by statute during the last seventy years. "Legislation has almost without exception proceeded on the lines " of removing particular instances of hardship without regard to "legal principle. The consequence of this is that the rules now " in force are nothing but a series of anomalies, and in order to " understand them the student is obliged to devote his mind in "the first instance to the apprehension of the principles which "the rules infringe, and when he has succeeded in this, he " has to encounter the labour of extracting the meaning of a "vast number of legislative enactments from the involved and " intricate language in which they are usually expressed. Each " successive reform has added something to the burden of know"ledge which the student must painfully acquire, but has taken "nothing away"; and the well-known text-book from which I have just quoted concludes with a summary of the effect of the Land Transfer Act 1897, to which I shall refer a little later on.

Then again, there is the most important question of protection from fraud. In this direction seems to lie the chief failing of the non-registration system. When a purchase of land is completed, the vendor hands over the bundle of deeds produced in support of his title; the possession of these deeds being of the utmost importance. I shall not attempt to enter into all the legal aspects of this question; but the most obvious risks are, first, that a person holding the deeds may oust a rightful owner who for some reason or other has parted with the possession of them, and secondly, the chance of the property when it is offered for sale having been mortgaged already; the only guarantee against which is the fact that the deeds are in the vendor's hands. In some cases, eren the possession of the deeds does not protect against charges. For example, there may be an annuity or rent-charge 


\section{The English Land Registry}

secured on the land. And there may be circumstances where a person having only a life interest would hold the deeds and be able to deal with the property as if he had the fee simple.

Many years ago attention was directed to remedying all these defects of conveyancing by means of registration of title. It was found that such a system was successfully worked in other countries, and the promoters of the reform were not deterred by the obvious difficulties of the conditions in England from trying to get it adopted there. During the last forty years three schemes have been tried. The first two proved quite unsuccessful. Then, after great opposition, registration in its present form was sanctioned by Parliament and put into operation, and it has now been worked long enough to afford the opportunity of weighing its merits, and forming some conclusions.

It is important to distinguish between registration of deeds and registration of title. The first is a public record of dealings, and the second of ownership of land. In both cases the object is to facilitate dealings and prevent fraud. But while the former is used with private investiga-

Registration in various countries. tion and the usual forms of conveyance, the latter is intended to go much further towards simplifying and cheapening transactions in connection with land. By means of a Government guarantee of title, private investigation can be dispensed with, and the process of dealing is to be carried out by an inspection of the register and fresh entries, combined with the use of short forms as in the case of stocks and shares. The whole arrangements are to be of such simplicity that a person of average intelligence could, if necessary, carry it out without recourse to professional help. To understand properly the English system, one must know something of the registries, either of deeds or title, in force in various countries. The Scottish system is, no doubt, familiar to you. All deeds of ownership of land or incumbrances on it must be registered in the General Registry of Sasines in Edinburgh, and no title to Scottish land is held to be complete without it. The title, however, is not registered; there is no Government guarantee of title, and a private investigation is necessary on every dealing. A somewhat similar system is in force in certain districts of England, in France, and all other European countries, except Germany and Austria-Hungary and a canton of Switzerland. In Middlesex and Yorkshire there has been a register of deeds since the reign of Anne. English professional opinion has been on the whole favourable to these registries, as supplementing the ordinary process in its weakest part; and even in our own experience we have probably come across instances of the protection they afford. Prior charges are disclosed, and the duplication of conveyances or mortgages, which has been the means employed 
in some cases of fraud, is prevented. As an example of this class of fraud, about tro years ago there was a case in the Central Criminal Court where tro properties were fraudulently mortgaged seventeen times over, and two other properties twelve times over. In France, various complications enter into the working of the registers, which I need not go into; but in Scotland the system seems to work very satisfactorily.

There are two systems in force in Ireland; a record of dealings and one of ownership. In the case of the first, all dealings are compulsorily registered, and priority depends on the time of registration. Non-registration does not invalidate an instrument, but renders it liable to be defeated by a subsequent registered instrument. The ownership record is similar to the English system under the 1875 and 1897 Acts, with this important difference, that in England registration is largely voluntary, while in Ireland there is a large class of lands the owvership of which must be registered, though in the case of the remainder it is voluntary. Title can be registered with either (a) full ownership, that is, ownership in fee, or $(b)$ limited ownership, for example, tenant in tail for life. The registration is conclusive evidence of the title to the land, and upon it all transfers and devolutions appear, any instrument of transfer being ineffectual till it does appear on the register. Charges are made by an instrument of Charge which, when registered, has the effect of a mortgage by deed. Generally speaking, the ownership of lands purchased by tenants under Land Purchase Acts must be registered. The ownership of any other land may be registered; and, if voluntary, it may be removed at any time.

In Germany and Austria-Hungary registration of title has been worked for some considerable time with remarkable success. As these countries were specially visited by the Registrar of the Land Registry, Mr. C. Fortescue Brickdale, and thoroughly examined and reported upon by him, it may be useful to mention briefly the chief features of his report. The system in those countries is very like that provided for under Lord Westbury's Act of 1862; every kind of interest in land being capable of registration. As will be noticed later on, in this respect it differs from our present English system. The result is a complicated record; but, notwithstanding this feature, it is said to give complete satisfaction. Sales and mortgages are arranged with remarkable ease and rapidity, and cheapness and security. The fees in Prussia, for example, are on an ad valorem scale reaching $7 \mathrm{~s}$. for $£ 100, £ 1,10$ s. for $£ 1000$, or

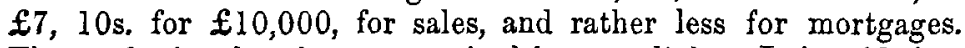
The professional assistance required is very slight. It is said that ten to fifteen days is the outside time occupied, though sometimes the matter can be completed in one day, there being generally no 
interval between the contract and conveyance. Mortgages are settled in three days. The only title shown is a copy of the register. In Prussia all conveyances are now made verbally by declaration of the parties in the presence of the land registrar; and the vast majority of country sales are concluded without any legal assistance whatever. It must be borne in mind, however, that the staple work of Continental registries is connected with very small transactions ( $£ 50$ and under); and allowance must be made for this in comparing the simplicity of the proceedings with the arrangements in England, where the average transaction is very much higher. In considering the risks one may run, the sum involved of course forms an important element in one's calculations. It is said that the system affords great facility for lending on mortgage, and that an immense business is carried on by the Real Credit Institutions and Land Banks, which are enabled to lend without any delay or expense beyond the registry fees; moreover, that this facility of dealing is possible in spite of the entries in the registers themselves being far more complicated than those recorded under the English system. Interests under wills, family charges, life estates and co-ownership, entails and settlements, are recorded and are sources of complication. There are no certificates of title, except in Prussia, where mortgage certificates are issued. It is of some interest, in view of the transition state in which registration is in in England, to note how the system was introduced into Germany and Austria. It was gradually applied province by province, and district by district, the Government Land-Tax Register showing the person for the time being in ostensible possession of the land; and although Absolute Titles are everywhere registered, very little documentary evidence of title was required, considerable reliance being placed on the local notices and advertisements and information from the land-tax books. In the Rhine provinces, the formation of the register is still going on. Few disputes, we are told, have arisen as a result of this method of procedure, partly due no doubt to the smallness of the holdings.

In the United States there is a registry of deeds; but the indexes are so badly arranged and of such bulk, that a search is very difficult and often impossible. This feature of land dealings, combined with the difficulties of American conveyancing, has resulted in Title Guarantee companies as a safeguard against the risks run; though it is said that registration of title is looked on as the only satisfactory protection, and it is already being adopted by some states. In Illinois, for example, titles can be voluntarily registered after an official in restigation and advertisements, and become Absolute after five years. After that time all adverse claims are barred. Registration gives a good title for sale pur- 
poses. The system does not affect short leases, highways, easements, taxes, or special assessments.

Australia and New Zealand afford examples of countries where title registration has been successfully worked for many years. The conditions of such countries would, it might be thought, be specially favourable to the system, and they would therefore form no criterion in judging of its applicability to this country. But it would appear that in Australasia the obstacles to the introduction of the system were very great. Surveys had been so defective and boundaries so indefinite, that to grant an indefeasible certificate was a matter of considerable difficulty. And even in the question of title there were many complications; land that had been granted by the Crown years before, having been frequently since dealt with in a very loose fashion. The system in force in these colonies, called after the name of its originator the Torrens system, was introduced into South Australia in 1857, and during the next seventeen years was adopted successively by all the other Australasian Colonies. Its main features were compulsory registration for all new grants, and voluntary for existing grants of land. A certificate is issued, being a duplicate of the register page, with a plan of the land. Estates for life and in remainder can be registered as well as estates in fee simple; but trusts are excluded from the register, although a caveat can be obtained to protect the beneficiaries. An insurance fund was established, to be formed out of a small payment to be made on first registration. Short statutory forms of transfer and charge must be used. Opinion in the colonies seems to be unanimous in favour of the system, which, from its simplicity and cheapness, is considered a great boon. It must not be overlooked, however, that all the titles brought compulsorily on the register were new grants direct from the Crown. Such tenure of itself conduces greatly to simplicity. A large proportion of the registered titles were of this sort; and it has been claimed that to the older ones, where registration was voluntary, the system is not well adapted. Registration is in force over two-thirds of Canada. There are three varieties; in British Columbia a system similar to that under Lord Westbury's 1862 Act to which I shall refer later on; in the North-West Territories, the Torrens system; while in Ontario the principles of the Land Transfer Act 1875 have been adopted. Strong evidence was produced at the World's Real Property Congress held in Chicago in 1893, as to the success of registration in the Dominion, and weighty testimony was given as to its great advantages over the old system.

I have purposely restricted the length of my remarks on registration in other countries to a bare outline of the subject. They are partly based on some notes by Mr. C. Fortescue Brick- 


\section{The English Land Registry}

dale, B.A. (London: Horace Cox), to which reference should be made by any one requiring further information.

Passing now to the English system, it is necessary first to mention the Land Registry Act 1862, which provided only for registration with an indefeasible (or what is now

known as an Absolute) title. Under this Act regis- The English tration was voluntary, and no alteration was made in the traditional modes of conveyancing. The expense

Registry.

and difficulty involved in the necessary investigation were, however, considered onerous; landowners did not come forward ; and the legislation proved practically abortive. Only 411 titles were registered, and of these 15 were subsequently withdrawn, either wholly or in part. Voluntary registration was also a feature of the Act of 1875 ; but with the idea of meeting some of the diffculties under which land is held in England, and of encouraging owners to register, a new principle was introduced. There were invented three classes of title, A bsolute, Qualified, and Possessory, under either of which registration could be obtained. Even with these facilities, however, but little advantage was taken of the system, and only 299 titles were registered. There is conflicting evidence as to the reasons for the failure of this Act. Whether the idea was well founded or not, there seems to have been a general impression that trouble, delay, and expense would be involved in getting the Absolute Certificate; that the Qualified title was rather detrimental than otherwise; and that the Possessory title was not worth getting.

During the next twenty years there were various unsuccessful attempts at legislation, until the passing of the Land Transfer Act 1897. This not only confirmed the principal features of the Act of 1875 , but also introduced a radical change. Registration was made compulsory in certain districts on all sales of freekolds and leaseholds having forty or more years to run or two lives to fall in. The intention of the system under the two Acts was to facilitate the transfer of land by (1) obviating the necessity of investigating past transactions the effect of which is exhausted, (2) relieving the purchaser from responsibility regarding subsisting settlements and trusts affecting the vendor's title, (3) simplifying the method of effecting transfers of land and charges, and (4) providing an Absolute guarantee of title. Its main feature was the establishment of a Government registry, in which registration must be compulsorily effected in either of three ways, namely, with an Absolute, Possessory, or Qualified title.

To obtain an Absolute title, the Applicant has to produce an Abstract in the usual form, with all deeds and documents relating to the title, just as is usual under the non-registration system. The title is then examined by the Registrar, and advertisements are 
inserted in the newspapers for objectors, if any, to come forward within two months. When this period has expired, and the title Absolute has been approved, the solicitor makes a statutory Absolute declaration to the effect that all deeds, writings,
Title. and instruments of title, and all leases, charges, and incumbrances affecting the title and material facts have been disclosed, that the plan comprises the land in question, that the rents are actually received as set out in the title, and that the value of the land does not exceed $\mathfrak{f}$. The registration is then completed, and a Land Certificate of the following form handed to the proprietor:-

\section{Form 66.-Land Certificate. (Rule 258.) \\ LAND REGISTRY.}

Land Transfer Acts, 1875 and 1897.

\section{Land Certificate.}

This is to certify that the freehold (or leasehold) land in the Parish of and County of (here fill in a short description of the land, or reference to the filed plan) is registered with absolute (qualified, good leasehold, or possessory) title under No. . Copies of the entries in the Register (and of the filed plan of the land) are within.

$$
\text { Dated the day of }
$$$$
19 .
$$

$$
\text { (L.S.) }
$$

The effect of first registration of freehold land with an Absolute title seems to vest in the proprietor an estate in fee simple, subject (1) to the incumbrances on the register, and (2) to rights and liabilities (such as succession and estate duty, taxes, tithes, quit-rents, rights of common), but free from all other estates and interests whatsoever. The proprietor has a Government guarantee, and can then dispose of his land, it is said, without delay, risk, or trouble. In future there will be no title to investigate. A purchaser cannot require any further evidence of ownership than that afforded by an inspection of the register and a statutory declaration as to those matters that are not dealt with as incumbrances. A transfer of the property would be effected by the execution of the following short form, and a fresh entry in the register:- 
FORM OF TRANSFER.

District

Parish

No. of Title

Date

In consideration of $£$ hereby acknowledged, I, $A$. $B$., of

hereby transfer to $C$. $D$., of

the land comprised in the title above referred to.

Any reasonable additions which the parties may wish to make are allowed.

If, after examination of the title, the Registrar thinks that it can be registered subject to some qualification, say for a limited period or subject to certain reservations, the title is accordingly registered as a Qualified title; but the applicant can, if he wish, refuse such a title and fall back on the Possessory Certificate. This option is of some importance, as meeting objections raised to this part of the system. It was said that the Qualified Certificate would be simply a slur on the owner's title; that it was bringing into prominence some defect which might depreciate his land, but which under non-registration conditions would have probably been no bar to his dealing with it satisfactorily. On the other hand, it is stated by the Registry officials that this view of the Qualified title is a wrong one. The certificate could state how far the guarantee goes, and its advantages would be that in many cases the time to elapse before such a title would be practically absolute, would probably be short; moreover, that on a sale, an owner could put in a condition to fit the qualification, just as is done under the ordinary circumstances, but without the trouble and expense of having his title specially investigated for the purpose. It should be mentioned that no application can be made for a Qualified title. Although I thought it best to state the features of this class of certificate, there has apparently been no demand for this part of the system, and it has been practically dropped. Our attention need therefore be directed only to the other two classes.

To get the full advantage of registration of title, owners must register with Absolnte Title. But it was felt that to enforce registration in this form, would be too drastic a reform for this country; and under the compulsory provisions of the Act, a purchaser can register with a

Possessory Title.

Possessory Title. This does not involve any investigation by the department. A certificate is granted on the following evidence that the applicant is the proprietor of the land, namely, either 
(a) A conveyance, assignment, or lease to the applicant, or other document entitling him to apply for registration, or

(b) a statutory declaration by the applicant, or his solicitor, to the effect that the former is entitled to the property, accompanied by the latest documents of title in his possession.

The first of these alternatives is the simplest and that most usually adopted. The application must also contain sufficient particulars by plan, or otherwise, to enable the land to be fully identified on the ordnance map kept at the registry. No advertisements for objections are inserted. When the registration is complete, a certificate in the same form as in the case of the Absolute title is handed to the proprietor, except that the following words are added :-

"The Possessory Title hereby certified does not affect or prejudice the enforcement of any estate, right, or interest adverse to or in derogation of the title hereby certified which was subsisting or capable of arising on the day of registration."

Registration with a Possessory title has the same effect as with an Absolute title, except that it does not affect any right adverse to the title of the first registered proprietor subsisting or capable of arising at the time of registration. At each subsequent dealing with the land, the same forms of transfer and charge can be used as in the case of an Absolute certificate. The title up to the time of registration must be investigated as under the ordinary conveyancing system; but the title after that time would not require investigation, and the only evidence of dealings since registration would be the entries in the register. There are certain cases where deeds might have to be retained. For example, in a building estate there would be restrictions that may have to be adhered to as long as the estate exists. It has been urged as one of the chief failings of the system of Possessory title, that the simplicity of dealings must be marred by the requirement of inspecting deeds containing such restrictions; and similar objection has been raised in the case of a leasehold property where the covenants of the lessor and lessee must be kept in view throughout the lease. As against this objection, however, it is said that any one can apply to have such restrictions put on the certificate, or he can at any time search the registry for them. In a transfer of property the restrictions would appear; or if the title is an Absolute one, they would be noted on the certificate as a matter of course. 
An important feature of the Possessory Title is that after a certain number of years it should for all practical purposes be accepted as an Absolute one. Time will obviate the necessity of enquiring into the dealings prior to registration, just as under the ordinary circumstances such dealings can be often neglected up to a comparatively recent date. Forty years is the longest period a purchaser can require a title to be shown for freehold land, if it begins with a purchase deed; and it is quite possible that a cautious solicitor might refuse to regard the Possessory Certificate as an Absolute one till the full term had expired. But this would be far too long to wait for the full benefits of the Absolute title; and for reasons to which $I$ shall refer later on, the need of amending the scheme to facilitate the earlier conversion of Possessory titles into Absolute, made itself pressingly felt. With the object of supplying a remedy, fresh rules were introduced last year. A proprietor who has been six years (or more) on the register, can apply for an Absolute title on exceptionally favourable terms. Where the first registered proprietor is a purchaser on sale, or where the title has been fully investigated, the stringency of the registry's investigation may be relaxed, and, it is said, the official enquiry into the earlier title would be a very simple matter indeed. The fees have, moreover, been reduced as regards land in compulsory districts, and the method of payment rearranged. They now include all incidental costs, such as fees of counsel, searches, advertisements; and if the application is refused, nearly the whole is returned. When the land has been already registered, and the application is made immediately upon a dealing, in many cases the fee paid for the dealing is allowed for, with the result of leaving no immediate fee to be paid at all.

This amendment of the scheme relaxing the stringency of the investigation in certain cases has met with strong adverse criticism from the legal profession, although the objections are not shared by all solicitors. It is said that this rule was adopted contrary to the advice of the majority of the Rule Committee, and there was some talk of the Law Society withdrawing their nominee on that Committee. At a recent meeting of that Society a resolution was passed regretting that so short a period as six years had been adopted, and expressing the opinion that it was dangerous and unfair for the Registrar to possess so wide a power of converting a Possessory into an Absolute title. It must, however, be remembered that, although there must be many cases where a solicitor employed cannot for his orn safety neglect technical flaws or slight risks because he might be liable, in the event of a loss, to make it good out of his own pocket, there hardly seems the same objection to the Registry taking risks that in many cases might be nominal. The insurance fund, 
to which I shall refer later on, would make good the loss arising from any defect. The chief objections against the new scheme seem to lie in the fact that this fund might be unduly pressed upon, and might have to be supplemented out of the pockets of the taxpayer. This objection is raised genuinely in the interests of the public; but I think that most business men would consider that the Registry might well run a number of risks, provided they were not too heavy, to get the system put on a much better working basis by means of this improvement. We have evidence that no proper precautions would be neglected, and $I$ see that in a paper read at a meeting of the Law Society which has been very highly spoken of by his profession, the author, Mr, Gribble, frankly states that he does not apprehend practical evil from limiting the enquiry into title. Besides the facility of dealing with the property with the short statutory forms wherever these are possible, the immediate advantages of Possessory title are (1) security from fraud as the result of registration, (2) clearness of description and definition of the property, (3) all dealings subsequent to registration the effect of which has been exhausted, can be entirely neglected, (4) in the case of leaseholds where the lease is registered immediately on being granted, the Possessory title has practically the effect of an Absolute title. I have referred in an earlier part of this paper to the protection from fraud obtained in those districts where there is a registry of deeds. It has been suggested for the consideration of insurance companies and other important bodies in the position of mortgagees of land, that they could obtain a similar protection in any part of the country, by making it a condition of their loans that the property to be mortgaged should be registered with a Possessory Title. The cost would not be heavy; and while the landowner would obtain the ultimate benefits of registration, mortgagees would be protected. Of course the mortgagee who made the stipulation would not get the full benefit himself, because he would be lending on a title prior to registration, and as this would not be investigated by the Registry there might be some undisclosed fraud. But the registration with Possesscry Title as I have shown is some safeguard in itself, and after it has been effected, all subsequent mortgagees of the same property would benefit. The only obstacle to such a course seems to lie in the fact that competition might prevent one company stipulating for registration, as the borrower's solicitor would take the loan to another who would dispense with the requirement. But the idea is well worth the consideration of insurance companies.

The clearness of description and definition of the property, which accompanies registration with Possessory title, as well as 


\section{The English Land Registry}

Absolute title, carries certain advantages. There is often some discrepancy between the description of the property as stated in a deed and its actual state as shown on the revised ordnance map; and most of the cases of delay occurring in the registration process are due, it is said, to this cause. It might, I think, be fairly claimed by the Registry officials that the person getting registered should set against the cost, the benefit of having his property correctly mapped and defined, as well as the other advantages of registration.

Then we come to the third advantage of Possessory title registration. All dealings subsequent to registration the effect of which has been exhausted, can be neglected. Under the old system, the deeds relating to these would be retained, and perused over and over again. But the register will show at a glance who is the present proprietor, and whether there are any cautions or restrictions entered, and an inspection of the Charges Register will disclose the only incumbrances that must be enquired into. The only exceptions are short leases, and grants of easements, etc., which are not always discoverable from title-deeds produced in the old way. I am aware that here I am touching on the difficult legal points connected with dealings off the register. These have perhaps given rise to more adverse criticism of the present system than any other of its features. And when the decision in a caseCapital \& Counties Bank v. Rhodes (Ch. Div. 1903, i. 631)—was given in 1903, there was a widespread opinion that the Act had been judicially proved to be a complete failure. In the case referred to, it was held that after land had been placed on the register, the legal estate will pass by an unregistered deed; that, for example, there is nothing to prevent the passing of the legal estate by an ordinary mortgage deed executed by the owner in fee, whether he is, or is not, registered as proprietor. It was further held that the term "proprietor" is somewhat misleading, for persons entered on the register of proprietors need not have the legal estate vested in them, nor even any estate in the land; that in short the register of proprietors is not material for the purpose of ascertaining where the legal estate is. The Land Registry officials do not regard, however, this decision as seriously as some of their legal opponents. They have all along been aware, they state, that it was possible to deal with property off the register. This feature was indeed dealt with by the Registrar, Mr. Brickdale, in his work on the Acts. In Lord Justice Cozens Hardy's judgment no reference was made to section 16, subsec. (2) of the 1897 Act, which puts a further practical difficulty in the way of persons who rely on estates created off the register. The clause is as follows: "Where the vendor of registered land is not " himself registered as proprietor of the land or of a charge giving 
"a power of sale over the land, he shall, at the request of the "purchaser and at his own expense, and notwithstanding any "stipulation to the contrary, either procure the registration of him"self as proprietor of the land or of the charge, as the case may be, "or procure a transfer from the registered proprietor to the pur"chaser." If, for example, a mortgagee takes a mortgage off the register, he would be at the mercy of the mortgagor in the case of a sale. Although he might have registered a caution to protect his mortgage, the purchaser from him would probably require to be registered, and the latter could not obtain registration through the mortgagee because he would have no locus standi, and would not be recognised by the registry. The result would be that the mortgagee would have to go to the mortgagor, the registered proprietor, to get his assistance in obtaining registration for the purchaser; and few lenders would care to run the risk of having to depend on the mortgagor to this extent.

Three times as many leaseholds as freeholds were registered during the years 1899-1902, so that it is important to consider Leaeeholds. specially the advantages of Possessory title with Leaseholds. regard to the former. A purchaser of a lease cannot enquire into the freeholder's title, and in mortgages it is unusual for the lender to do so. Hence in respect of dealing with the lease where it is registered immediately on, or soon after, being granted, the Possessory has practically the effect of an Absolute title. Except in special circumstances, a leaseholder cannot of course be registered with an Absolute title. He can only procure the latter, if the freeholder has already been registered in this way. To meet the case of leaseholds, revised rules were introduced in 1903, under which these interests can be registered under what is called a "Good Leasehold Title". Where registration has been procured on the granting of the lease, the effect of such a title would not differ from that of the Possessory Title, except that solicitors' costs for subsequent dealings would come under the reduced Land Registry scale, and not be chargeable by item; but the provision, where the lease has been some years in furce, seems to meet a very necessary requirement in respect of interests so much dealt in as leaseholds. A person who is the original lessee can obtain the "Good Leasehold Title", on satisfying the Registrar that he has not encumbered or dealt with the land. I have gone much more fully into the incidents of Possessory Title because, as I shall show, we are very much more concerned at present with this part of the system than with Absolute Title.

The Register is kept in three divisions, the ProThe $\quad$ perty Register, the Proprietorship Register, and the Register. Charges Register. The Property Register contains the description of the land, giving the parish, the name of the 
house or estate with a reference to a filed plan, and notes relating to mines and minerals, or rights and liabilities :-

\section{A. Property Register.}

District, London.

Title No, 20,000.

PaRish, St. George's, Hanover Square.

\begin{tabular}{|c|c|}
\hline No. & Description of the Land, etc. \\
\hline & $\begin{array}{l}\text { 2 Jan. } 1899.5 / 99 \text {. Freehold dwelling-house in } \\
\text { the parish of St. George's, Hanover Square, } \\
\text { in the County of London, known as Jo. } 50 \\
\text { Duke Street, Jayfair, shown and edged } \\
\text { with red on the filed }(1 / 4) \text { plan Yo. } 20,000 \text {. }\end{array}$ \\
\hline
\end{tabular}

The Proprietorship Register states the nature of the title, and contains the name, address, and description of the proprietor of the land, and cautions, inhibitions, and restrictions affecting his right of disposing of it :-

\section{B. Proprietorship Register.}

\begin{tabular}{|c|c|c|c|}
\hline No. & \multicolumn{2}{|c|}{ Proprictor, etc. } & Olservations. \\
\hline 1 & 2 Jan. 1899. $5 / 99$ & $\begin{array}{l}\text { Possessory Title registered. } \\
\text { First Proprietor, Sir James } \\
\text { Robinson, of } 50 \text { Duke Street, } \\
\text { Mayfair, Bt. }\end{array}$ & $\begin{array}{l}\text { Value declared, } \\
\qquad 10,000 .\end{array}$ \\
\hline
\end{tabular}

The Charges Register contains incumbrances prior and subsequent to registration, and covenants and rights adversely affecting the land, and all such dealings with registered charges and incumbrances as are capable of registration. The following is a specimen entry:-

\section{Charges Register.}

\begin{tabular}{|c|c|c|}
\hline No. & Charges. & Obserrations. \\
\hline 1 & $\begin{array}{l}\text { Charge to John Smith to secure £1000 payable } \\
\text { on the with interest } \\
\text { at per cent per annum payable half. } \\
\text { yearly on the day of } \\
\text { and the }\end{array}$ & $\begin{array}{l}\text { Lease dated of } \\
\text { numbered 1 in yellow on plan to James } \\
\text { Brown for 99 years from 25 March 1904. }\end{array}$ \\
\hline 2 & \\
\hline
\end{tabular}

VOL. II. 
Briefly stated, the procedure to obtain registration is as follows, The applicant, or his solicitor, attends with the purchase deed on which the application is founded, and identifies the property on an Index Map which shows the position and extent of every registered property and is open to public inspection. He then arranges for the preparation of the filed plan and the draft entries for the register. The fees paid, there is nothing further to do, unless some question arises in the course of the registration. When the necessary processes have been completed inside the office, that is, among other things, the preparation of the plan, and any surveying incident to this, the Land Certificate is despatched. This Certificate has to be produced on every dealing involving a change of ownership or on the entry of a charge, and can therefore for most purposes be relied upon as evidence of title. There is a card Index of Proprietors' names which is open to inspection by registered proprietors only. There are only two methods of dealing with land on the register, namely, by transfer or charge. Other dealings such as settlements, wills, or leases for less than 40 years, must be made in the same form as before. This provision serves to keep the register from becoming complicated; while the rights of beneficiaries under such deeds are protected by cautions, inhibitions, or notices.

As we are chiefly concerned with mortgages of land, the proCharges. visions of the system in this respect are of importby means of the following short statutory form :-

CHARGE.

District...............................

Parish.

No. of title.

(Date.) In consideration of $\boldsymbol{f}$ , I, A. B., of , hereby charge the land comprised in the title above referred to with the payment to $C$. $D$., of , on the day of

19 , of the principal sum of $£$, with interest at per cent per annum payable halfyearly (quarterly) on the day of in every year.

When it has been registered, a note is made in the Charges Register and in the Land Certificate, and the following Certificate is issued to the creditor:- 


\section{CERTIFICATE OF CHARGE.}

District.........London.

Parish.........Vol..., p..... Title No....Charge No...

This is to certify that a Charge affecting................

was registered on the. $19 \ldots$ against the Title above referred to. Copies of the Charge and of the entries in the register relating to that Title, and of the filed plan comprised in the Charge, are annexed hereto.

The charge implies covenants for principal and interest, and powers of entry, foreclosure, and sale; and it can be transferred by execution of the following short statutory form of transfer :

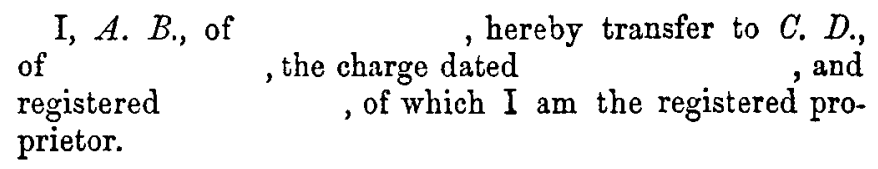

I have mentioned the difficult points that arise in connection with what lawyers call 'the legal estate'. Under an English mortgage in the ordinary form, the property is conveyed to the mortgagee subject to a right of redemption. Subject to such right, the land belongs to the mortgagee, or in other words, he has 'the legal estate' in it; and on exercise of his power of foreclosure, or on going into receipt of the rents, he is taking over his own property. The new statutory form of charge does not confer on the chargee the legal estate. $\mathrm{He}$ is, therefore, not in quite so good a position as a mortgagee under the old form; but the positions can be approximated to a great extent by a slight variation of the statutory form. The following words may be added to the statutory form to convey the legal estate:-

And I, the said $A . B$., hereby grant the said land unto and to the use of the said $C . D$. in fee simple, subject to redemption on payment to me of the said principal sum and interest on the day above mentioned for that purpose.

This would imply a conveyance of the legal estate on a transfer of the charge, or a reconveyance on discharge of the loan. Although, as I have mentioned, the statutory form of charge does not put a lender in quite the same position as under the ordinary mortgage deed, yet for nearly all practical purposes the charge is as good as the latter. It includes powers of entry, sale, and fore- 
closure. The chargee can convey the legal estate to a person buying from him, by executing the following form of transfer:-

In consideration of $\mathfrak{E}$ , and in exercise of the Power of Sale conferred by the Charge dated the 19 , and registered the transfer to $C$. $D$., of , I, $A . B$., hereby the title above referred to, discharged from the said Charge.

Upon obtaining an order for foreclosure absolute, a chargee becomes absolutely entitled in equity to the land charged; and be is entitled to be registered as the proprietor. Apparently he may be so registered on production of the certificate of charge, and an office copy of the order for foreclosure absolute, without production of the land certificate, and the effects of such registration would seem to be to vest in him the legal estate in the land.

There are a few other points to be noted as regards charges. They rank according to the order in which they are entered on the register, and not according to the order in which they were executed. A chargee does not require the Land Certificate. Where the title is a Possessory one, the deeds must be handed over to the mortgagee. There are two other ways of taking a mortgage of registered land, namely, by (1) a mortgage off the register with a caution registered, or (2) a mortgage off the register with a statutory transfer of the land to the mortgagee, and a caution registered on behalf of the mortgagor to protect his equity of redemption. The most effective way of securing himself is for a chargee to insist on being registered as proprietor, and this course is recommended in Williams's Real Property. The statutory form of charge seems to meet the case of a mortgage of leasehold land, as the chargee would have his power of sale, and he would appear to be free from liability for the rent and covenants of the lease. The chargee is neither lessee nor underlessee of the land charged. It is doubtful, however, whether in case of a breach committed by the mortgagor of any covenant contained in the lease, the chargee would have any locus standi to apply to the Court for relief against the forfeiture which might be so incurred. On this account, it is said, it is advisable for a mortgagee of registered leasehold land to take an underlease made by deed in the ordinary form as well as a registered charge. The question naturally arises as to whether a mortgagee of unregistered land in a district where registration is compulsory on sale, should enter a caution to protect his mortgage. Apparently it is not necessary to do so. The mortgagor could not get registered with Absolute Title, without production of all the title- 
deeds held by the mortgagee; and to get a Possessory Certificate, he would have to produce his purchase deed. A second mortgagee in the case of such land should, for want of holding the deeds, register a caution against the registration of the property.

One of the advantages claimed for the system is the facility with which loans could be arranged by merely depositing the Land Certificate. If all titles were registered as Absolute, no doubt there would be such a convenience, but as the bulk of titles are Possessory at present, a notice of the deposit has to be registered and paid for in addition to the deposit of the deeds as under the old process. Bankers' practice has not been simplified yet; in fact, they now have a special department to carry out the registration.

Examples of the fees charged as amended by the latest Rules are as follows :-

(1) For compulsory first registration (that is, with Possessory Title), and for registering sales and mortgages of land registered with Absolute or Possessory Title-

\begin{tabular}{|c|c|c|c|}
\hline Value. & \multicolumn{3}{|c|}{ Registry Fees. } \\
\hline$£ 25$ & $\mathfrak{f} 0$ & 1 & 6 \\
\hline 100 & 0 & 6 & 0 \\
\hline 1,000 & 3 & 0 & 0 \\
\hline 10,000 & 14 & 0 & 0 \\
\hline 50,000 & 25 & 0 & 0 \\
\hline
\end{tabular}

(2) For registration with Absolute, Good Leasehold, or Qualified Title-

Three times the fee for registration with Possessory Title, with a minimum of $£ 3$.

If a Possessory Title is already registered, or in course of registration, the fee paid for the Possessory registration is allowed for, the additional fee payable for Absolute Title amounts to $£ 2$ for the first $£ 1000$, and $£ 1$ per $£ 1000$ afterwards; there being also a deferred fee to be paid on charges or transfers afterwards. These fees are to provide all the Registry Office Expenses and an Insurance Fund to indemnify any person suffering loss from an error in the register incapable of rectification. If this fund is at any time insufficient to pay indemnity for any loss chargeable on it, the deficiency is to be paid out of the Consolidated Fund of the United Kingdom. As I have already mentioned, such a fund is part of the registration systems in our Colonies, its objects being to facilitate the granting of an indefeasible title.

Besides making registration compulsory, the 1897 Act pro. 
vided for the manner in which it was to be applied. It is Application of necessary to quote the clauses referring to this, in the system. order to understand the circumstances under which the system was started, and the stage its extension has reached at the present time. I am mentioning the circumstances in some detail, because they throw light on the public attitude to the system and the opposition the promoters have had to meet at every stage :-

"Her Majesty the Queen may by Order in Council declare, " as respects any county or part of a county mentioned or " defined in the Order, that on and after a day specified in " the Order, registration of title to land is to be compulsory " on sale, and thereupon a person shall not, under any con"veyance on sale executed on or after the day so specified, " acquire the legal estate in any freehold land in that county " or part of a county unless or until he is registered as "proprietor of the land."

"In the case of every Order proposed to be made under " this section, notice shall, six months before the Order is " made, be given to the council of the county to which " such Order is proposed to be applied. A drait of the " proposed Order, together with the name of at least one "place within or conveniently near to the county where a " district registry office will be established shall accompany "the notice, and shall also be published in the Gazette." "If within three months after receipt of the draft the " county council, at a meeting specially called for the pur"pose, at which two-thirds of the whole number of the "members shall be present, resolve, and communicate to the "Privy Council their resolution, that in their opinion com"pulsory registration of title would not be desirable in their " county, the Order shall not be made."

"No further Order shall be made under this Section until

" the expiration of three years from the making of the first "Order."

In November 1897 the Privy Council gave notice to the London County Council that they proposed to apply the Act to the County of London, registration to commence at 1 July 1898. Thereupon the County Council communicated with the City Corporation and a number of other important bodies to ascertain their views. Those consulted included the Vestries and District Boards, seventeen Railway Companies, the Incorporated Law Society, the Institute of Bankers, the Surveyors' Institution, Auctioneers' Institute, Ecclesiastical Commissioners, Building 
Societies, and Lord Portman. The result was overwhelmingly against the proposal. Of the important bodies just mentioned, 44 sent in replies against it, while only 12 vestries or district boards were in its favour. At the same time some well-known building societies sent in petitions against the proposed application of the Act. The chief reasons urged against were (1) the expense and delay that would be added by compulsory registration to dealings by way of sale or mortgage, (2) registration while optional has met with little favour, (3) the size of the interests and large number of properties that would be affected. The proposed Order was, however, sanctioned by the London County Council by a majority of two to one, and came into force in certain parishes on 1 January 1899 , and in others on various dates, ending with the City of London on 1 July 1900.

As regards the City, the application of the Order was the subject of great opposition. A petition of owners, lessees, and others interested in property was presented to the Common Council, praying for a revocation of the Order of July 1898 so far as it related to the City; and it was then resolved by the Council to present a petition to the King, asking for a repeal of the Order and an enquiry to be made into the working of the Act and the expediency of applying it to the City. Before this was done, however, the City Solicitor wrote to the Lord Chancellor asking him to suggest some mode of obviating the petition; but as the only reply received was to the effect that his Lordship had no observations to make, the petition was presented. In it the petitioners alleged that when the Land Transfer Act was before Parliament it was intended that the City should have the same power as the County Councils of vetoing the introduction of the system into the district under their administration; but that the section protecting the City in this way was left out on the Lord Chancellor stating in the House of Lords that "the City must know extremely well that he would not be a party to any Order affecting them without consulting them and considering their wishes, either as to the application of the Act or as to any arrangements for a registry there or otherwise". This was considered a sufficient undertaking, and the section was struck out and the Bill passed. The petitioners further pointed out that when the Lord Chancellor had written to the Lord Mayor asking whether a proposal to extend the compulsory provisions of the Act would be acceptable in the city, the Common Council had instituted an enquiry among bankers, merchants, professional men, and other influential citizens, but finding opinions practically unanimous against the introduction of the system, they had informed the Lord Chancellor that the adoption was not expedient, that no furtber communication had passed till the Order of 18 
July 1898 by which registration was made compulsory on and after 1 July 1900 ; though subsequently the effect of this Order had been postponed till 1 July 1902. It was further stated that the Common Council had reason to believe that compulsory registration would be attended with grave inconvenience and drawbacks; that expense and delay incident to the purchase or mortgage of landed property would be largely increased, and that, having regard to the large number of properties, the difficulty of identification, to the fact that buildings were largely dealt with in separate rooms and floors, and the consequent great diversity of interests in such buildings, compulsory registration should not be extended to the City. And in conclusion, the petitioners stated that they had received further representations from bankers, merchants, building societies, and professional men, that compulsory registration would lead to great delay, expense, and complication, and they prayed for further postponement till after an enquiry had been made. It is instructive to note the Privy Council's answer to this petition. They stated that it was unnecessary to deal with the petition so far as it relates to objections to the principles of the Act; that Parliament had fuil cognisance of these objections and passed the Act without a division, and with a remarkable concurrence and support; that the special reasons adduced for excepting the City did not appear of serious weight, inasmuch as they would apply to a large part of the area already within the scope of the Act. The Privy Council further went on to say that the date of the Order had been postponed repeatedly; that the registry was now in thorough working order; and there seemed reasonable ground for doubt whether the suggested difficulties would arise. It was also pointed out that the time allowed had not been utilised by the City authorities in preparing any scheme, as suggested by the Lord Chancellor, for facilitating the working of the Act. The Common Council made a further attempt at resistance, but without avail. They maintained that the circumstances under which the Bill was allowed to pass unanimously were on the undertaking of the Lord Chancellor, both in the House of Lords and in his letter to the Lord Nayor, as to the City's right of veto; and that as regards the statement that the time allowed had not been utilised for preparing a scheme, the result of enquiries showed so determined an opposition to the application of the Act to the City that the preparation of a scheme was considered inexpedient and unnecessary. The system actually came into force in the City of London in July 1902. It has not yet been further extended. An Order was made applying it to Yorkshire, but several Local Authorities sent in resolutions to the effect that full enquiry should be made before anj extension of the system beyond the experimental area; and the County Council decided against its applica- 
tion to their district. A similar decision was arrived at by the Northamptonshire County Council. It is said that the Lord Chancellor is now considering the application of the scheme to all the big towns.

The circumstances I have just mentioned show the strength and nature of the opposition to registration of title, both in principle and in the form adopted in the Acts. On the question of the demand for it, it is a little diffcult to form a conclusion. Theoretically, probably the majority of people would approve of the system. But when it was purely voluntary, existing landowners would not come forward; and it would now appear that persons compulsorily registering on purchase wish to take advantage to no greater extent of the main feature, the Absolute title. The figures for the four years 1899-1902 certainly seem to show this. There were 46,151 Possessory titles registered, and only 76 Absolute. No later figures are available. At the same time, this paucity of Absolute titles may be partly due to other causes. The existence of the Registry, and the advantages it offers, may not be widely known. The compulsory part of the process is done by a solicitor as a purely formal matter, and the Land Certificate put away with the deeds, without the client hearing of it. But even if a purchaser knows of the Absolute title and its effect, he may be deterred from applying for it, by a doubt whether his title, which might be quite good enough to hold, would not show some technical flaws. The Land Registry say, indeed, that there exists no disposition on their part to discover such flaws; that the standard adopted so far has been neither above nor below that which is found to be sufficient for practical safety; moreover, that no case has occurred where registration has been refused as Absolute, the Registrar having power to accept a good holding title though open to technical objection. Whatever may be the cause of the small number of Absolute titles, it may be fairly claimed by the opponents of the system that its chief objects have not been attained. Purchasers finding that they can register in a cheaper way, with a Possessory title, are content to let the property remain subject to the old modes of convejancing, especially if they do not anticipate parting with the property. Although before many years have elapsed, such Possessory titles may be for all practical purposes as good as Absolute titles, to make the system a success it was necessary to devise a scheme to encourage applications for the Absolute certificate. With this end in view, new facilities in the form of relaxation of the stringency of the investigation, and reduction of the fees, were adopted. Whether they will produce a marked increase in the number of Absolute titles or not, it is impossible to say, as no figures are available; but there is evidence that they have not yet had much effect. 
Whether registration in principle is adapted to the conditions of this country, is of course a disputed question. It should be possible, however, to form some conclusions as to the particular system provided by the Acts, now that it has been in force for six years. As I have shown, the chief cry of its opponents is for an enquiry into its working before it is extended further. This call for an enquiry is becoming more and more pronounced, and is made chietly on the ground that the Act of 1897 was allowed to pass on the understanding that it was to be experimental for three years; though on the strict wording of the Act there seems to be no obligation on the authorities to institute such an enquiry. As to the many objections urged against the system as shown by its practical morking, it should be remembered that the Act was got through only by a method of compromise. Some of the points on which its opponents now attack it are the very ones on which the promoters gave way to meet the opposition. $\mathrm{Had}$ the system been applied in a much more drastic way, there seems little doubt but that some of the failings of the present arrangement would have been absent. For example, a provision for the compulsory registration of Absolute titles in certain circumstances might have proved no hardship. Had this been possible, there would not have been the same cause for complaint that the system has added expense and delay to the old process. At present, the cost of registration is an additional, not a substituted, item. As to the alleged delay, it is no doubt true that a day or two is required to carry through the registration. If a longer time is required, it is generally in connection with the mapping, and is rather a condition of the early stages of the system than when it has been long in force and the somewhat loose definitions of property have been largely reduced to more exact boundaries.

As you are probably aware, there has been rery strong opposition on the part of some of the legal profession. It would naturally be said that a solicitor's view must be self-interested. If dealings with land are facilitated in the way proposed, he would lose a material part of his earnings, and has therefore every reason to oppose its adoption. But after a careful examination of the history of the question, I am quite satisfied that this motive has very little to do with the opposition referred to, but that it has proceeded from a cause reflecting credit rather than otherwise on the profession. Other sections of the public may not be prepared to adopt their views, but it is clear that solicitors have opposed registration in the genuine belief that it is against the public interests. Strong efforts were made with this in view when the subject was before Parliament. But since the Act was passed, members of the profession on the whole 


\section{The English Land Registry}

have done their best to make the system work as smoothly as possible. It must of course be borne in mind that, from the nature of his work, only the solicitor can be thoroughly aware of the difficulties and complications that may arise in the working of the system. There is ample evidence of the existence of a large number of such difficulties. The author of Williams's Real Property, after observing how the intricacy of the present land Jaws has been rather intensified than otherwise by modern legislation, goes on to state: "The Land Transfer Act of 1897 affords " an extreme instance of the method which the legislature has "pursued. . . The registration of the title to land which the "Act has made compulsory on sale in certain districts, is an "advantage to landowners in so far as it saves them the expense " of investigation of title on every sale or mortgage. But when "the student finds that under the law so introduced, lands may "be held and disposed of for all manner of unregistered estates "and interests as well as for the estates and by the means of "conveyance recognised on the register, he will note a likely "source of further confusion. The difference between legal and " equitable estates in land is sufficiently puzzling to a student: " but we are here threatened with a new distinction, not " necessarily coinciding with that difference, between registered " and unregistered estates. Those who have now to learn, and " those who have to teach the law of real property, can best "appreciate the pressing need for reform which shall not merely " change but really simplify the law. But it is not likely that " this will be effected unless the same conditions can be again "secured as resulted in the passing of the Fines and Recoveries "Act. The author of that statute was at once a lawyer well "versed in conveyancing practice, a master of legal principles, " and a consummate draughtsman; and his work was not marred " by what are called 'amendments' made in its passage through "the legislature." Then, again, the Registrar himself, in his book on the two Acts, refers to the difficulty of forecasting the changes in practice that must follow such "drastic reforms" and "revolutionary enactments" as those provided for in the Acts. And there is the case Capital \& Counties Bank $v$. Rhodes, where the intricacies of the Acts were referred to by the judges.

In forming a conclusion, it seems to me there is this important consideration to be kept in view. As long as a method of dealing with land requires the public to throw upon a solicitor the responsibility of protecting their interests, he must, for his own protection, provide for every risk he can foresee. In many other classes of property, men of business carry out their own transactions and take the risks themselves. Their methods of dealing are in hundreds of cases subject to risks from the strictly legal point of 
view, and now and then a loss occurs, and the practice is adjusted. But commercial life will continue to be carried on in this way. And the same conditions must be applied to land, if simplicity, cheapness, and quickness of dealing are to be attained. When all titles are registered as Absolute, and a number of adjustments, which such a radical reform must necessarily require, have been effected, there seems no reason why the proposed system should not work well.

\section{DISCUSSION.}

The Chairman (Mr. G. M. Low, Vice-President).-As usual, this paper has been put into the hands of two referees in order that they may be in a position to open the discussion. On this occasion the gertleman who is to begin the discussion is a member of the bar who has been chosen by the Council to fill the position for some time occupied by Mr. William Harvey, namely, that of watching over any proceedings in the courts that may be of interest to our profession, and furnishing reports thereof for insertion in the Transactions. I have now to ask Mr. Wark to open the discussion.

Mr. J. L. WARK, Advocate. - I have had very great pleasure in listening to the paper that Mr. Hart has just read, and in attending for the first time a meeting of your Faculty. I do not think I can deal very adequately with the subject he has treated; for, as indicated in the paper, the subject necessarily involves a number of intricate legal questions the discussion of which would require a more thorough knowledge and experience of English real property law than I can pretend to have. It is difficult for us here, with our complete registration system, to realise how it has been possible to do without a register in England for so long. But the proposal now made is evidently of too drastic a kind, because the opposition with which the Land Transfer Acts have been met shows that there are very serious objections to driving this novel species of register, namely, a register of 
title, like a wedge, into the complicated system of English land law as it at present exists. Only the other day I noticed that, at a legal gathering in Leeds, the President of the Board of Trade gave an assurance that it was not the intention of the Government to extend the compulsory operation of these Acts in the immediate future; and Mr. Lawson Walton, K.C., said in reply that that announcement was a great relief to the legal profession in general. So the objection to the new register seems to be as strong as ever in England. Mr. Hart has referred to the fact that the question of registration of title has come up here in Scotland also. But it has hardly yet become a practical question with us. Our existing Scottish system of registration of deeds is almost a half-way house to registrution of title, and under it we already enjoy nearly all the benefits which registration of title is said by its advocates to confer. First of all, we have the fact that, in order to complete a title to land, an entry of the conveyance upon the register is required, so that the register is a complete record of ownership in land for the whole country. Secondly, we hare the search-sheet-not an official part of the register, but a very reliable and useful one-by an examination of which we can see practically at once how a particular parcel of land stands as regards both title and incumbrances. Considering the system of registration of title as it is at present being attempted in England, and as Mr. Hart has described it, we must feel most of us that, however theoretically perfect it may be, and however well it may work once it has been introduced, there are considerable difficulties in the way of its introduction. The difficulties in England are possibly greater than they would be here; for here the matter would be much simplified by the very fact of the existence of our present General Register. I do not doubt that, once introduced, such a system could be practically worked. I think its usefulness and adaptability have been proved by experience, not only in our Colonies, but also in older countries, such as Prussia, Austria, etc., where the law of real property, like our own, is based upon feudal principles. There is one instance given by $\mathrm{Mr}$. Brickdale in his report, of a property in Prussia consisting of a three-Hatted building owned by different proprietors, the owners having a common interest in the entrance, and proprietors on the upper floors having common interests in the staircase. All these interests, and mortgages, liferents, etc., of the various parts of the property, can be quite easily detailed in the register, and can be recorded in exactly the same way as under our present system. One difficulty which his been suggested by Mr. Hart with regard to mortgages, does not exist with us here, namely, the conversion of a mortgagee's right into one of real security only. This is one of several apparent novelties introduced under the new Act in England, which are really taken from our Scottish system. For instance, it is quite familiar to us in Scotland that mortgages rink in priority, not according to the date of the bond, but according to the date of entry on the record ; and the interest of the Scottish bondholder is precisely the same kind of interest as the new Act gives a mortgagee in England. He does not in his bond get an absolute conveyance subject to right of redemption, but merely a conveyance in security. I understand that under the new Act what is given to the chargee in England is very much the same thing-a real security over the land; he does not get what he formerly had under the old system, an absolute conveyance of the land vesting in him the legal estate, so that, in the event of foreclosure, he was really entering into his own property. The bondholder in Scotland never had any such right: indeed, as you know, it was not until 1894 that a bondholder had the right to foreclose. He had the right to sell, after certain elaborate procedure, but not to foreclose. Therefore I should think no objection would be taken in Scotland at all to the new system, so 
far as the question of mortgagee's interest is concerned. The question, however, is really whether, having regard to our existing system, any such plan as is described and is now working in England not merely can be introduced and worked, but is worth while introducing. There is a large body of legal opinion in Scotland which holds that the difficulties and the initial cost of introducing the reform would be so great, and the resulting advantages so small, as to make the change decidedly not worth while. It is said that our courts would be blocked with all the questions of boundary and other conreyancing matters which would arise at one time, and that it would be almost impossible to get the register into working order if registration of title were made universally compulsory. I do not agree with this opinion ; for, if such a system as this English srstem were applied here, a great many of our Scottish land titles could be registered as absolute titles without much difficulty. As I have already said, the present register would help very much in this process. Certainly there would be questions as to boundaries, but a general surver might be made to settle them. But if such a system were attempted in this country, the feeling of the legal profession, I think, would be that it should be done unirersilly, and that a much more effective attempt shonld be made to enforce the registration of absolute title than has been made in England. I agree with Mr. Hart that a good many of the difficulties and objections made to the new system in England arise from the facilities giren under the 1897 Act for the getting of something less than absolute title. If more effort had been made to enforce application for absolute title, possibly some of the difficulties might never have arisen.

Mr. A. E. SpragUE.-I had a practical illustration recently of the beneficial effect of such a system of registration as Mr. Hart describes. An Australian gentleman who wished to borrow on a block of buildings in London, explained to me that the lawyers had been working at the title for over a month, and he expected that their bill would amount to over $£ 20$ O before he got the transaction settled. In Australia a similar transaction would be a simple matter. As far as my memory serves me, he would have had to gret from a surveror a certificate of the extent of the property; go to a professional (probably an official) valuer, hand in the surveyor's certificate, and get a raluation certificate enclosed in a sealed envelope. He would then go to the land registry, and obtain the certificate of title. These documents would enable him to obtain the loan at a total cost of about fire guineas, and the transaction could be completed in a couple of days at the most. It seems to me, therefore, that, if such a system could be introduced, it would be a great advantage to the nation, as it would save expense and the loss of time of skilled professional men in examining over and over again deeds of title to land. But to start the system is bound to cause expense, and I think the reason for the opposition to it lies in the fact that this expense comes out of the pocket of the individual. For instance, I have a house with the title to which I am quite well satisfied. I had to pay for the examination of the title, but if $I$ had to register it I should have to pay more, and the registration would be of no advantage to me though it might be to my heirs. Two points are not clear to me, namely, first, what is the nature of the disadrantage to a registered chargee in not having the "legal estate" ? Apparently he can foreclose, or enter into possession, or sell the property, and I should like to know the precise difference caused by his not possessing the "legal estate"-whether its absence could cause actual expense or trouble in realising his security, and if so, in what circumstances? Secondly, why should any one take a charge "off the register"? Is there any adrantage in so doing? Would it not be both cheaper and safer to take a charge in the regular way on the 
register? I wish to express my thanks personally to Mr. Hart for this paper, and for having come from London specially to read it.

The Chairman.-We bave the honour of the presence of the highest official in Scotland connected with the system of registration of deeds, Mr. Hope Finlay, Keeper of the Register of Sasines, who will perhaps farour us with any remarks which may occur to him in connection with the subject of the paper.

Mr. J. Hope FI'LAT, W.S.--This subject-of special interest to me as Keeper of the Land Register for Scotland-was first brought under my serious notice by one of your members, Mr. A. H. Turnbull, in his paper of 1890, and I have since given it much consideration. It is a very fascinating ideal to get a certificate of title which you can hand to your banker or to any man in the street, and with which, going together to the register, you can arrange an immediate loan or a sale, in a few minutes and for a few shillings. Accordingly I have applied myself to consider how the Scottish system could be adapted to it. I first calculated, with the assistance of my staff, the cost of conveyancing in Scotland for a whole year (1894, I think), and I laid my information before the Scottish Office and more than one departmental committee. And I will only say this, that, when the public of Scotland show a distinct, earnest, and sincere desire that this system of registration of title should be introduced into Scotland, there will be no obstruction on the part of the Register House, but we will be prepared to give facilities for making the change easier and safer than in England. I have also had opportunities of meeting heads of the Society of Writers to the Signet, of the Society of Solicitors before the Supreme Courts, and of the Glasgow Faculties, and I feel warranted in saying that these professional men all agreed that, when the time came that the public really desired to have this new system, the legal profession would not allow any selfish interest to stand in the way. Now we have to consider the subject on its merits. In England it was necessary to have some change and improvement. In Scotland there was no such necessity, unless distinct adrantage was to be gained. There are various points of difference in the laws and practice in the two countries. In England the custody of title is a most appreciable right of property. It is not so in Scotland. For example, the Duke of $\mathbf{A}$. is in possession of an entailed estate in this country. His heir, the Marquis of B., who is entitled to succeed if he survive him, wants to raise money on his "expectations", and goes, say, to a London financial agent. He has no deeds to show; but the lender's Scottish agent comes to the Register House and finds recorded the deeds under which the estate is held; and, with the assistance of these, a bond is prepared and the transaction completed, a policy of insurance of course being taken out on the borrower's life. But it is said-" look at the delay of the Scottish system; how much more rapidly Mr. Brickdale manages". But where is the delay? The delay is not in the conveyancing, or in the registration. It takes place mainly before the conveyancer gets his instructions, and arises on the question of value, the rental, etc. These points do take time to arrange, and only when they are settled do you come to the question of title. Now, if you go to the Register House, and turn up the search-sheets, you will in five minutes find how long A. B. has owned his property, and what mortgages there are ; and you will walk away with as much information as to his title as if you read the deeds for a fortnight. But "there may be a mistake in the title". How many mistakes of any real importance have you seen, out of the thousands of titles you have had through your bands in your respective offices? In how many cases has a transaction been thrown out because of a radical defect in the title? There may have been many technical slips, to be overcome by the substitution of a new deed; but so 
far as the real ownership of the proprietor or borrower is concerned, an important error is very rare, so that the investigation of title need very seldom be accompanied by great delay. Let me give you a case in point. A bank sent its law clerk to the Register House a short time ago, to see the search-sheet of a certain property, the owner of which wanted $£ 5,000$ on loan immediately, and the bank wanted to see whether it could give him the money at once. He looked at the search-sheets, and it did not take him five minutes to get the information he desired. Of course the formal deed will follow, but the bank, knowing its customer, was able to grant the cash credit at once. It is a fallacy that the conveyancing in Scotland really causes a serious delay. In England business flows on in a fairly steady stream all through the sear. It is entirely different in Scotland, as, in consequence of the customs of the country, one half of the deeds are received on two days of the year, Whitsunday and Martinmas. During the month of May we get 13,000 deeds sent in to the Register of Sasines, and about 4,000 in June. With about 16,000 deeds in hand at once, Mr. Brickdale would find his system of maps rather difficult to work and to keep up to date. His map surveyors would have their work cut out for them if, say, ten large ducal estates had to be surveyed at once, besides the other 15,990 ordinary properties. In fact, the habit of having transfers of properties and loans, and changes of tenants, arranged at Whitsunday and Martinmas, causes such a mass of work at these periods that, if the English system of registration were introduced, we should not get the adrantages anticipated. It is maintained in England that prevention of fraud is another great advantage of this new system. Fraud is practically unknown in Scotland. During my sixteen years at the Register of Sasines, there have been only two cases of fraud brought under my notice. One was the case of a discharge which was being put on the register. The writ was in our hands when the fraud was found out. The other case was where a well-known west-country lawyer had forged a number of bonds; but I altogether repudiate that as a case of fraud in connection with my register because, if any of the parties had only searched the register, they would have seen that no such bonds were recorded. He had not only forged the signatures to the bonds, but also the usual certificate of registration, which, however, he signed, not with my name, but with the quite unknown name of "William Jones". Let me say that I take a great and sympathetic interest in Mr. Brickdale's experiment. I know his ability, and I have a great belief in the resources of himself and of the men who are acting with him. It would be foolish and ungenerous to say his experiment was a failure at present. One looks with great interest to the future of his register in Eugland, but up to the present his experiment is absolutely useless in a question of its introduction here. We will not look at a possessory title, or a qualified title, but only at an absolute title; and we have no experience as yet of absolute title in England. I do not think Mr. Brickdale will succeed until the Government of the day makes registration compulsory. It may not have to be compulsory registration for absolute title. But if all deeds for a period of twenty years were put on the register, then the register for a proper prescriptive period would completely disclose the state of every title, and form a safe and reliable foundation for granting a certificate of absolute title with government guarantee. I consider Mr. Hart's paper is a very useful one on a subject attracting general interest, and $I$ am indebted to the Faculty for the opportunity of being present today.

Mr. Erxest T. Skat.-I am glad to see it admitted in Mr. Hart's paper that lawyers are not biassed in this matter; for, although most of the conveyancing reforms carried through Parliament during last century 


\section{The English Land Registry}

originated on the part of the legal profession, we are accustomed to hear that their opinions on these matters are founded on self-interest. The English Land Registry policy is to some extent condemned by $\mathrm{Mr}$. Brickdale's own dictum, for, writing in 1886, he said that no system of land registration really beneficial to landowners would require to be forced on them. His registry is trying to force one upon them now. I do not suggest that our system here is not capable of improvement, but I think the system of which Mr. Brickdale is the protagonist would not be of any use here. What is claimed for it is security of title, cheapness, and despatch. The only way you can get, in any real sense, security of title, is by registering an "absolute title", and the manner of obtaining this is in several respects faulty. The fact that only two months are giren for objections coming forward to the grant of absolute title, is a decided weakness. It seems to me that this procedure is against the interest both of private individuals and public bodies. The parties interested may be out of the country, and never in so short a time hear of the advertisement; or, in the case of a public right of way, it is doubtful whether in two months the funds necessary to institute an objection could be guaranteed. Another decided objection is the question of plans. It is not right that the indiridual, who perhaps does not want to register, should have to pay for this plan, and still less should the general public be called upon to pay. It would not do to take the ordnance survey map : the boundaries of estates are not always shown correctly-a hedge may be shown as a boundary, while the true boundary is beyond it ; or where a stream at one time formed the boundary its course may hare altered, and it by no means follows that the one owner's ground is extended and his neighbour's restricted by such alteration of a stream's course. A minute examination of the whole country would be necessary ; but it would cost millions, and who would pay? The advertisements would bring in every conceivable sort of claim in connection with rights of neighbours, and the pressure of work on the courts would be enormous. There would be a grand feast for the lawyers, and it might be in their interest to get the system extended as soon as possible! It is suggested that possessory title is half-way towards absolute title, but in the case of lands in Scotland there are so many burdens, restrictions, servitudes, etc., to be mentioned in the schedule that, after all, even the so-called absolute title is not really absolute. The qualified title nobody wants, and the chief claim of the possessory title is that it contains the declaration that $A$. B. claims the estate of $X$. Under the present registration-of-deeds system we do as much by recording a disposition. In England a possessory title mar be made absolute after six years ; but $I$ do not think it would be wise to change from our twenty-year prescription to six years. In the early part of the paper it is explained how in England expense is increased by the fact that the conveyancer often gets counsel's opinion on title. I do not think he is so often consulted here. In fact, the higher branch of our profession sees very little of conveyancing, whereas it comes under the attention of the conveyancing solicitor every day. Absolute title would not prevent that research which it is the main object of this system to put out of the way. You have a long list of registered documents, and to satisfy yourself you must go through the deeds as now, in every single case and every kind of case. Burdens and servitudes have a distinct effect on the value. They cause a serious reduction upon the apparent value of the estate, and it seems to me that, in order to discover the burdens, etc., noted on these absolute titles, the deeds creating such burdens would bave to be gone through in the same way as at present. With regard to the claim of despatch made on behalf of this system, we in Scotland, as soon as our deed is noted in the minute book of the Register of Sasines, are safe. With

VOL. II. 
regard to the Torrens system, it is a striking thing that when the gentleman whose nime has been given to that system became the owner of a property in England, he carefully abstained from registering it. Like others, I should like to see our system perfected, but I do not think the adoption of the method described would help us.

Mr. IAN MacINTYRe, W.S. - There is one practical difficulty in this question, namely, as to the distinct estates of superiority and property in land in Scotland where the description of the lands in the titles is the same, and yet the estate-the legal estate-is different; I do not see how that is to be worked out on a plan. On the general question of whether it is really of any great adrantage to facilitate the transfer of land, and to make it transferable as readily as stocks and shares, I doubt the expediency of this, and think the result would be, not that the land would be distributed among more people, but that it would soon all be owned by the millionaires.

Mr. D. W. Roвs, S.S.C.-I do not think I can contribute much to this interesting discussion on Mr. Hart's very able and singularly impartial paper; but I am glad of an opportunity of expressing the pleasure I have experienced in being present and listening to it. I have a good deal of sympathy, as every one must have, with the proposals for registration of title. So far as I am concerned, my synipathy is given simply on the score of saving the terrible trouble of having a set of titles conned over and orer again by different agents. The question of expense does not trouble me so much! With regard to the reception of the reform in England, I must say that I humbly concur with the Keeper of the Register of Sasines in thinking that the authorities have not gone the right way about it, and that registration of title ought to be preceded by registration of the deeds of transfer, and I should add, by deposit of these deeds permanently at the registry. If not digressing from the subject under discussion, I should like to say that the feeling is growing very strongly among conveyancers, of the necessity of having all writs relating to property "registered for preservation". A great deal of time is lost, and worry caused, in hunting for writs which are in the hands of different agents. I agree with Mr. Skae that we can never in Scotland expect to get as simple a title as seems to be possible in England. Our title must disclose references to the deeds which contain burdens, and these deeds must accordingly be deposited, or at least recorded in the registry, so that the parties interested can examine them. The burdens are sometimes even found in titles of neighbouring or other properties.

Mr. A. Hewar.-As a member of Council, I join with others in extending the hospitality of the Faculty to Mr. Hart, a Fellow of our sister Institute in London, and in thanking him for coming so far and bringing to us such an instructive paper as that to which we have just listened. While we have derived much benefit from him, I think he has probably gained some advantage himself from his present visit to North Britain, where he has possibly learned something more about our legal system. That system being based on the Roman, is older, and, we modestly think, better than that in South Britain. I have some sympathy with those who have difficulties in connection with a system of land registration; for we must remember Britain is an old and conservative country, where our titles and all their vast complications have, like Topsy, "growed", and may appear to the lay mind to be in a topsy-turvy condition. It is different in new countries. Take Winnipeg, for example, with its population of 60,000 , where little more than a quarter of a century ago their main street was merely an Indian trail. It was easy there to begin and keep up a correct register of the "progress of title" of every property, more especially 


\section{The English Land Registry}

where all the land is carefully mapped out in blocks, so that the extent and identity of tach can easily be defined and described. The system of registration there is a great protection and comfort to those of us who do murtgage business in that rapidly-growing prairie city, which is destined to become possibly the greatest and most influential centre in the vast Dominion of Canada. Perhaps I may suggest to Mr. Hart that the registration system in the old country of Germany exists because fire insurance is compulsory there. It is therefore necessary to know exaculy what are the properties, and who are the owners of the same whom the state can compel to insure.

Mr. V. Marr.--Mr. Hope Finlay has referred to the possession of titledeeds being a valuable security in England. 'There is one poin: in favour of the land registrution system which in connection with that I may be allowed to mention. It has more reference to England than to this country. In the short statement of the Objects and Practical Working of the Dystem of Kiegistration of Title, published by Mr. Brickdale, the Registrar to the Land Registry, it is pointed out under Observation No. 10 that when a banker's equitable mortgage is being settled, the deposit of the land certificate in the case of registered land takes the place ot the deposit of title-deeds under the non-registration system. It is stated that the creditor has the additional advantage of being enabled to protect himself by notice on the register. This notice is given in terms of the rules made under the Act, by which any party interested may apply to the court, or to the registrar subject to an appeal to the court, to make an entry inhibiting any dealing with the registered land or registered charge - such application to be accompanied by the consent in writing of the registered proprietor, or to be supported by the statutory declaration of the applicant and further evidence if deemed necessary. It would, however, seem that the court or registrar may make or refuse to make any order or entry, and generally act in the premises in such manner as the justice of the case requires. Frequently insurance offices are interested in funds held in trust, either by absolute purchase or by a loan on the security of an immediate or reversionary interest. When these funds are invested in stocks or shares, the purchaser or lender may protect himself by placing a distringas on the funds involved, or a stop order if they are in court ; but in cases where the funds are invested in real property, either absolutely or by way of mortgage, the purchaser or lender cannot, as a rule, prevent trustees realising the funds without his knowledge, as he cannot call for a deposit of the deeds. Now in the case of a reversion to registered property, might not a notice be put on the register and so safeguard the purchaser or lender? It would seem that, under the rule $I$ have just referred to, while the court or registrar might not make the desired entry on the application of the purchaser or lender as such, this might be done on the application of the trustees if they are the registered owners. It might be as well to make it a condition that the trustees, assuming they are the registered proprietors, should consent in writing to an application to the court or to the registrar to register such a notice. Although, of course, the system of registrition has not been in vogue long enough to allow the operation of testamentary bequests, and the consequent purchase and sale of reversionary interests, to take effect in the case of registered land to any appreciable extent, yet existing trusts might happen to have funds invested therein, and it seems to me that it might add appreciably to the value of some reversions if such a safeguard could be applied.

Mr. A. D. LiNDSAY TURNBCll.- In connection with the difficulty of map construction, mentioned in this discussion, I may mention that while in Chicago I had some experience of the methods in use there. The city 
and district is divided into "blocks" and "sections", which can be easily specified. This point is not perhaps realised by those who would apply to London, or even to Edinburgh, those systems of land registration which are so useful in new countries. Old countries are not divided into sections in this manner, and every property, consequently, would require to be elaborately described in any form of transfer.

Mr. Hewat. - That is also the system in Winnipeg; the land is divided into sections.

The Chairmax.-It only remains for me now to express to Mr. Hart our very hearty and cordial thanks for his paper. It has indeed been one of great interest, and although a good deal has been said in favour of our Scottish system, he must not go away with the impression that we consider it to be incapable of improvement. The paper is instructive to us northerners, who have to deal largely with mortgages in England, where the laws relating to land are different from our own. I should also say how much we appreciate the fact that a member of the Institute has come to read a paper before the Fuculty here. That is just one of the evidences, accumulating from year to year, of the extremely cordial relations that subsist between the two bodies, and which are bound to be for the benefit of the profession at large. I have much pleasure in proposing a hearty vote of thanks to Mr. Hart for his paper.

Mr. HART, in reply, said-In thanking you for the kind reception you have given me tonight, I should like to express the pleasure it has given me to revisit Edinburgh and be among a number of old professional friends. I have not come here without learning a good deal about Scottish law ; but though several of those who have spoken have treated the subject from the point of view of the introduction of the system to Scotland, my idea was to present the paper to the Faculty on the basis that the members deal with English land in connection with mortgages and otherwise, and therefore require to consider the subject without reference to its application to their own country. It seems to me, however, that the Act could be much more easily applied to Scotland than to England, and that many of the difficulties met in England would not have to be met here. Mr. Sprague raised a very natural point, in asking what is the use of the "legal estate". That is a very difficult point to explain fully, and it would require an English lawyer to do so. But practically there would not be much in it, if business men were dealing with each other. It seems to be a technical definition that lawyers can hy bold of in certain cases, and very often comes up in connection with cases in court. On the question of fraud, I can quite understand how the register as applied in Scotland has prevented fraud. In England frauds are certainly much more common than one might have supposed. As regards the point as to whether a register like the Scottish one would necessarily make it easy to apply the new system, one must remember that in London the Middlesex registry of deeds was available and was made use of ; so that difficulties have occurred, notwithstanding the existence of a registry similar to the Scottish one.

Mr. Hope Finiar. - But there the registration was not compulsory, and that is just the cause of the trouble- the fact that the registry did not contain the entire transactions.

Mr. HART. - In that case, then, the London registry would not have the help that a new Scottish system would be able to get. I may mention that I have found, in studying the systems of different countries, that the Scottish deed registry is far and away the best of all the deed registries. $I$ was at first strongly opposed to the land registry system, but I think that what influenced me has influenced others-namely, attention was directed too much to the difficulties and complications. A good many of these have 


\section{The English Land Registry}

already been got over, and a good many more would disappear in time. The cost seems to me the principal objection. Every individual, as Mr. Sprague says, objects to pay an extra charge. He does not expect to part with his land for some time, and objects to be compelled to register. Several speakers have referred to the fact that the system may be easily enough applied in a new country. But it must be remembered that it is working in Germany, and though the great majority of the properties there are small in value, there must be properties presenting just as many difficulties as London properties; and I have myself found no evidence that the argument, which at first seems strong, that the system is not applicable to an old country, can be stipported by the facts one gathers from Germany, Switzerland, etc., where it has been working for many years. A great deal more might have been said on the subject. I have been limited by want of time and want of legal knowledge, but I felt that it might be of some value to present to you the main principles of the registration system which it is useful for us to know.

[In the Edinburgh Gazette of 27 January 1905 it is announced that, upon the recommendation of the Secretary for Scotland, the Lords Commissioners of His Majesty's Treasury have been pleased to sanction a proposal made by the Keeper of the General Register of Sasines, that the accuracy of official searches for incumbrances issued in his department should be guaranteed. This concession will apply to searches issued on or after 1 March 1905. The Treasury, if satisfied that a loss has been sustained owing to an error or omission in an official search, and that compensation for such loss cannot be obtained otherwise than from public funds, will be prepared to pay compensation out of moneys to be provided by Parliament. The decision of the Treasury upon any claim under this guarantee will be final. No claim will be considered after the expiration of six years from the date when a search has been issued.-ED. T.F.A.] 